\title{
De coronacrisis en de tragiek van ongelijkheid
}

\author{
Rosanne Anholt \& Marijn Hoijtink
}

'De coronacrisis raakt ons allemaal' is een veelgehoorde frase. Maar de coronacrisis raakt ons niet allemaal op dezelfde manier. Yvonne La Grouw (elders in dit nummer) laat zien hoe de coronacrisis de sociaal-maatschappelijke positie van vrouwen verslechtert en eerdere verworvenheden van de decennialange strijd voor vrouwenemancipatie en gendergelijkheid ondermijnt.

Andere gemarginaliseerde groepen worden op eenzelfde manier onevenredig hard geraakt. Zo treft Covid-19 vooral werknemers in precaire werksituaties en frontlinieberoepen, en werken de huidige coronamaatregelen kansenongelijkheid in het onderwijs en de bestaande armoedekloof verder in de hand. De coronacrisis heeft ook geleid tot een toename van racisme, xenofobie en een algeheel wantrouwen ten opzichte van minderheidsgroepen in de samenleving. Denk bijvoorbeeld aan hoe Aziatische Nederlanders sinds de corona-uitbraak worden geconfronteerd met racisme en stigmatisering, of aan de uitspraken van PVV-leider Geert Wilders dat 'Mohammed en Fatima' IC-bedden innemen ten koste van 'Henk en Ingrid', alsook een verdere criminalisering van dak- en thuislozen, asielzoekers en ongedocumenteerden.

Dit alles zou ons niet moeten verbazen. Crisisonderzoek laat al sinds de jaren negentig zien dat noodsituaties de structurele ongelijkheden in een maatschappij niet alleen blootleggen, maar ook verdiepen (onder andere Tierney, 2014). Zoals La Grouw ook stelt, hebben de ingezette crisismanagementstrategieën gericht op afstand houden, thuisblijven en thuiswerken geen of onvoldoende oog voor deze structurele ongelijkheden. De mantra 'we doen dit met z'n allen' weerspiegelt niet alleen een gebrek aan inzicht onder politici en beleidsmakers over de mate waarin de coronacrisis bestaande machtsstructuren, structurele ongelijkheden en kwetsbaarheden in stand houdt en uitvergroot, maar het verbergt die structurele ongelijkheden ook nog eens achter een schijn van sociale cohesie (Bowleg, 2020).

Wanneer we voorbijgaan aan een specifiek westers perspectief, zien we dat globale structurele ongelijkheden eveneens worden uitvergroot. In de 'Global South' komt de coronacrisis bovenop een opeenstapeling van andere crises: de klimaatcrisis, de hiv/aids-pandemie, structurele armoede, honger en politiek conflict. Terwijl westerse landen onderling betrokken lijken te zijn in een race om vaccins en sinds kort zijn begonnen met het vaccineren van zorgmedewerkers en kwetsbare ouderen, zullen landen in Afrika en Centraal-Azië pas in 2022 of 2023 toegang hebben tot vaccins (The Economist, 2020). Tegelijkertijd is het afgelopen jaar minder geïnvesteerd in onderzoek naar, of de behandeling van, andere ziekten zoals hiv/aids, ebola of de mazelen. Samengenomen betekent dit dat de jaren-

* Rosanne Anholt MSc is universitair docent bestuurskunde, afdeling Bestuurskunde \& Politicologie aan de Vrije Universiteit Amsterdam. Dr. Marijn Hoijtink is universitair docent internationale betrekkingen, afdeling Bestuurskunde \& Politicologie aan de Vrije Universiteit Amsterdam. 
lange inzet op armoedebestrijding en vredesopbouw in korte tijd teniet wordt gedaan (onder andere Valensisi, 2020), terwijl de kans op nieuwe conflicten toeneemt als gevolg van de groeiende ongelijkheid die Covid-19 teweegbrengt (Bloem \& Salemi, 2020).

Covid-19 legt wereldwijd de bestaande structurele ongelijkheden en kwetsbaarheden weliswaar bloot, maar de omvang en grootschalige gevolgen van de coronacrisis worden grotendeels veroorzaakt door een langere periode van teruglopende publieke investeringen in zorg, onderwijs en wetenschap, huisvesting, armoedebestrijding en ontwikkelingssamenwerking. De huidige crisis vereist dat we bestaande beleidsstrategieën herzien aan de hand van een intersectioneel beleidsperspectief. Op zowel lokaal als internationaal niveau kan een intersectionele benadering beleid responsiever maken voor de manier waarop, aan de ene kant, beleidsproblemen een verschillende impact hebben op verschillende groepen en, aan de andere kant, het beleid zelf voor verschillende groepen op verschillende manieren kan uitwerken. Intersectionaliteit, een term die inmiddels breed bekend is in zowel wetenschappelijk onderzoek als in de praktijk, kan worden aangewend om te begrijpen hoe individuen langs verschillende assen, waaronder gender, etniciteit, klasse en seksualiteit, discriminatie ondervinden (Cho, Williams Crenshaw \& McCall, 2013). Een intersectioneel perspectief laat zien hoe de coronacrisis vrouwen disproportioneel raakt (Connor e.a., 2020) en extra risico's met zich meebrengt als deze vrouwen vluchteling of migrant zijn, een laag inkomen hebben of een beperking hebben (onder andere Ryan \& El Ayadi, 2020). Een intersectionele benadering problematiseert een collectief 'wij'. Het maakt diegenen zichtbaar die voor beleidsmakers vaak onzichtbaar zijn, en kan daarmee de impact van beleid vergroten (Manuel, 2019).

De ongelijkheidscrisis die volgt op de coronacrisis vraagt niet alleen om zorgzaamheid als organiserend principe van beleid en bestuur, zoals La Grouw stelt, maar ook om bestuur dat in staat is om kritisch te kijken naar de wereld, het eigen handelen en de consequenties daarvan. Een bestuur dat in staat is om kritisch te kijken naar de zichtbare en onzichtbare machtsstructuren die het creëert en in stand houdt. De huidige crisis geeft aanleiding tot een herdefiniëring van wat goed bestuur behelst en welke prioriteiten het zou moeten nastreven vanuit een breder perspectief dan het westerse perspectief. Het moet nog blijken in hoeverre de hernieuwde aandacht voor publieke diensten, de zorg, het onderwijs en wetenschappelijk onderzoek zich vertaalt naar structurele investeringen die ten goede komen aan iedereen.

De coronacrisis is niet alleen een feministisch drama, maar laat ook de tragiek van wereldwijde, structurele ongelijkheden zien. Zoals Bowleg (2020) ook stelt: 'we're not all in this together'.

\section{Literatuur}

Bloem, J.R., \& Salemi, C. (2020). COVID-19 and conflict. World Development. doi:10.1016/ j.worlddev.2020.105294. 
Bowleg, L. (2020). We're not all in this together: On COVID-19, intersectionality, and structural inequality. American Journal of Public Health, 110 (7): 917-917. doi:10.2105/ AJPH.2020.305766.

Cho, S., Williams Crenshaw, K., \& McCall, L. (2013). Toward a field of intersectionality studies: Theory, applications, and praxis. Signs, 38 (4): 785-810. doi:10.1086/669608.

Connor, J., Madhavan, S., Mokashi, M., Amanuel, H., Johnson, N.R., Pace, L.E., \& Bartz, D. (2020). Health risks and outcomes that disproportionally affect women during the Cobid-19 pandemic: A review. Social Sciences \& Medicine, 266. doi:10.1016/j.socscimed. 2020.113364

Grouw, Y.M. La (2021). De coronacrisis is een feministisch drama, hoe gaan we dit samen oplossen? Beleid en Maatschappij, 48 (1).

Manuel, T. (2019). How does one live the good life?: Assessing the state of intersectionality in public policy. In: O. Hankivsky \& J.S. Jordan-Zachery (red.), The Palgrave handbook of intersectionality in public policy. Cham: Palgrave Macmillan, 31-58.

Ryan, N.E., \& El Ayadi, M. (2020). A call for a gender-responsive, intersectional approach to address COVID-19. Global Public Health, 15 (9): 1404-1412. doi: 10.1080/17441692.2020.1791214.

The Economist. (2020, 18 december). Rich countries will get access to coronavirus vaccines earlier than others. The Economist. www.eiu.com/n/rich-countries-will-get-access-tocoronavirus-vaccines-earlier-than-others/.

Tierney, K. (2014). The social roots of risk: Producing disasters, promoting resilience. Stanford: Stanford University Press.

Valensisi, G. (2020). COVID-19 and global poverty: Are LCDs being left behind? The European Journal of Development Research, 32: 1535-1557. doi:10.1057/ s41287-020-00314-8. 